\title{
PENGARUH WAKTU FERMENTASI TERHADAP PERSENTASE PENYISIHAN CHEMICAL OXYGEN DEMAND (COD) CAMPURAN LIMBAH CAIR INDUSTRI TAPIOKA DAN AIR
}

\author{
Umayi Belladiana, Wan Rizki Ansari, Setiaty Pandia \\ Departemen Teknik Kimia, Fakultas Teknik, Universitas Sumatera Utara, \\ Jl. Almamater Kampus USU Medan 20155, Indonesia \\ Email : ubelladiana@yahoo.com
}

\begin{abstract}
Abstrak
Penelitian pengaruh waktu fermentasi terhadap persentase penyisihan chemical oxygen demand (COD) campuran limbah cair industri tapioka dan air bertujuan untuk mengetahui pengaruh kualitas dan kuantitas gas bio yang dihasilkan dari limbah cair industri tapioka yang dikombinasikan dengan air. Penelitian ini dilakukan dengan mengkombinasikan limbah cair industri tapioka dengan air pada beberapa komposisi yaitu 100:0; 85:15; 65:35 ; $50: 50 ; 35: 65 ; 15: 85(\mathrm{v} / \mathrm{v})$ dengan starter kotoran sapi di dalam digester anaerobik sistem batch selama 24 hari dengan $\mathrm{pH}$ netral. Persentase penyisihan COD optimum yaitu pada rasio limbah cair industri tapioka dan air 15:85 dengan nilai 42,14\% dimana nilai COD pada hari ke-0 adalah $1723 \mathrm{mg} / \mathrm{L}$ setelah hari ke-24 adalah $997 \mathrm{mg} / \mathrm{L}$.
\end{abstract}

Kata kunci: limbah cair industri tapioka, air, digester anaerob, COD

\begin{abstract}
Study about the effect of fermentation time on the percentage removal of chemical oxygen demand (COD) a mixture of tapioca liquid industrial waste and water that aims to determine the effect of water quality and quantity of bio-gas generated from tapioca industrial wastewater combined with water. The research was conducted by combining tapioca industrial wastewater with water on several compositions, namely 100: 0; 85:15; 65:35; 50:50; 35:65; 15:85 $(v / v)$ with cow dung starter in the batch anaerobic digester systems for 24 days with a neutral pH. The optimum percentage of allowance for COD at the ratio of tapioca liquid industrial waste and water at 15:85 with a value of $42.14 \%$ where the value of COD on day 0 was $1723 \mathrm{mg} / \mathrm{L}$ after day 24 was $997 \mathrm{mg} / \mathrm{L}$.
\end{abstract}

Keywords: tapioca industrial wastewater, water, anaerobic digesters, $C O D$

\section{Pendahuluan}

Tumbuh dan berkembangnya industriindustri di Indonesia membantu peningkatan perekonomian dan kesejahteraan masyarakat Indonesia, tetapi disisi lain menimbulkan dampak yang kurang baik bagi lingkungan, yaitu adanya limbah yang dihasilkan sebagai hasil samping dari suatu proses pengolahan dalam industri. Limbah yang dihasilkan tersebut kadang kurang diperhatikan oleh pengelola industri dengan kata lain dibuang begitu saja tanpa melalui pengolahan limbah terlebih dahulu, sehingga membawa beberapa efek buruk bagi lingkungan [18].

Salah satu dari energi terbarukan adalah biogas. Biogas memiliki peluang yang besar dalam perkembangannya. Energi biogas dapat diperoleh dari air buangan rumah tangga, kotoran cair dari peternakan, sampah organik dari pasar, industri makanan dan sebagainya [17]. Pada dasarnya limbah dapat mengalami perubahan secara biologis sehingga dapat dikonversikan ke produk lain [1].

Perumusan masalah dalam penelitian ini adalah sejauh mana limbah cair dari industri tapioka yang hanya dibuang begitu saja ke tempat pembuangan dapat dimanfaatkan sebagai bahan baku gas bio menggunakan digester anaerobic sistem batch dan pengaruh adsorben kulit ubi kayu terhadap cairan dari outlet sehingga memenuhi baku mutu limbah cair.

Tujuan dari penelitian ini adalah mengetahui kualitas dan kuantitas gas bio yang dihasilkan dari limbah cair industri tapioka yang dikombinasikan dengan air menggunakan bioreaktor anaerobik sistem batch pada rasio tertentu dan mengetahui pengaruh penambahan adsorben kulit ubi kayu terhadap parameter TSS (Total Suspended Solid) cairan dari outlet sehingga memenuhi baku mutu limbah cair.

\section{Teori}

Ubi kayu (Mannihot esculenta) termasuk tumbuhan berbatang pohon lunak atau getas (mudah patah). Ubi kayu berbatang bulat dan bergerigi yang terjadi dari bekas pangkal tangkai daun, bagian tengahnya bergabus dan termasuk tumbuhan yang tinggi. Ubi kayu bisa mencapai ketinggian 1-4 meter. Pemeliharaannya mudah dan produktif. Ubi kayu dapat tumbuh subur di daerah yang berketinggian 1200 meter di atas permukaan air laut. Daun ubi kayu memiliki tangkai panjang dan helaian daunnya menyerupai telapak tangan, dan tiap tangkai mempunyai daun sekitar 3-8 lembar. Tangkai daun tersebut berwarna kuning, hijau atau merah [5]. 
Adapun proses pembuatan tepung tapioka di mulai dari proses pengupasan, pencucian, pemarutan, pemerasan, pengendapan dan pemisahan pati, pengeringan, penggilingan, pengemasan serta menjadi tepung tapioka [6].

Adapun limbah yang dihasilkan dari pembuatan tepung tapioka berupa limbah padat, cair dan gas yang mampu meracuni lingkungan [5] Limbah padat akan menimbulkan bau yang tidak sedap, apabila tidak ditangani dengan tepat. Limbah cair akan mengalami dekomposisi secara alami di badan-badan perairan dan menimbulkan bau yang tidak sedap. Bau tersebut dihasilkan pada proses penguraian senyawa mengandung nitrogen, sulfur dan fosfor dari bahan berprotein [2]. Penanganan yang kurang tepat terhadap hasil buangan padat dan cair akan menghasilkan gas yang dapat mencemari udara [7].

Gas bio adalah gas yang dihasilkan oleh aktifitas anaerobik atau fermentasi dari bahan bahan organik termasuk diantaranya kotoran manusia dan hewan, limbah domestik, sampah biodegradable atau setiap limbah organik yang biodegradable dalam kondisi anaerobik. Kandungan utama dalam biogas adalah metana dan karbon dioksida [12]. Tidak seperti bentuk lain dari produksi energi terbarukan, produksi energi biogas relatif sederhana dan dapat beroperasi pada skala kecil dan besar baik perkotaan dan di lokasi pedesaan, tidak ada batasan geografis untuk kerja teknologi ini [4].

Biogas merupakan bahan bakar yang bersih yang dapat mengurangi kerusakan mata dan paruparu [15]. Biogas hanya dapat terbakar apabila kandungan metana di dalamnya mencapai $45 \%$ atau lebih [13].

Arang yang merupakan residu dari peruraian bahan yang mengandung karbon sebagian besar komponennya adalah karbon dan terjadi akibat peruraian panas. Proses pemanasan ini dapat dilakukan dengan jalan memanasi bahan langsung atau tidak langsung di dalam timbunan, kiln, retorn, dan tanur [3].

\section{Metodologi Penelitian Bahan dan Alat}

Bahan yang digunakan adalah limbah cair industri tapioka dan air sebagai bahan baku, sebagai bahan pembantu digunakan inokulum bakteri anaerobik yang berasal dari kotoran sapi yang dicampur dengan air dengan perbandingan 1:1 yaitu $25 \%$ dari volume reaktor terisi $(500 \mathrm{~L})$ dan glukosa. Alat utama yang digunakan adalah digester anaerobik untuk proses fermentasi.

\section{Proses Pembuatan Gas Bio}

Limbah cair industri tapioka dan air dimasukkan ke dalam tangki digester yang memiliki volume $500 \mathrm{~L}$ dengan variasi komposisi limbah cair : air adalah 100:0; 85:15; 65:35; 50:50;
35:65; dan 15:85 (dalam \% volume). Kemudian ditambahkan starter (kotoran sapi) dan difermentasikan. Tangki digester dihubungkan dengan bladder (tempat penampungan gas) sehingga gas yang terbentuk akan masuk ke bladder. Volume gas diukur pada hari fermentasi ke-21. Bakteri anaerobik yang telah diaklimatisasi dicampur dengan limbah dengan perbandingan jumlah limbah : kotoran sapi adalah 75 : 25 (dari perancang digester), lalu diamati parameterparameter percobaan yaitu Chemical Oxygen Demand (COD). Interval pengamatan yang dilakukan dalam penelitian ini setiap 3 hari sekali.

\section{Penentuan Konsentrasi Chemical Oxygen Demand (COD)}

$10 \mathrm{~mL}$ sampel yang akan diuji dimasukkan ke dalama Erlenmeyer $250 \mathrm{~mL}$. Ditambahkan 0,2 g $\mathrm{H}_{2} \mathrm{SO}_{4}$ dan beberapa batu didih. Ditambahkan 5 $\mathrm{mL}$ larutan Kalium dikromat $\left(\mathrm{K}_{2} \mathrm{Cr}_{2} \mathrm{O}_{7}\right) 0,25 \mathrm{~N}$. Ditambahkan $15 \mathrm{~mL}$ pereaksi asam sulfat- perak sulfat perlahan-lahan sambil didinginkan dalam air pendingin. Dihubungkan dengan pendingin leibig dan didihkan di atas hot plate selama 2 jam. Didinginkan dan dicuci bagian dalam dari pendingin dengan air suling hingga volume sampel menjadi lebih kurang $70 \mathrm{~mL}$. Dinginkan sampai temperatur kamar, ditambahkan indikator ferroin 2-3 tetes, dititrasi dengan larutan FAS $0,1 \mathrm{~N}$ sampai warna merah kecoklatan, dicatat kebutuhan larutan FAS. Dilakukan kembali langkah-langkah diatas terhadap air suling sebagai blanko. Dicatat kebutuhan larutan FAS. Dianalisis blanko ini sekaligus dilakukan pembakuan larutan FAS dan dilakukan setiap penentuan COD.

Kadar Chemical Oxygen Demand (COD) dapat dilihat pada persamaan (1)

$\mathrm{COD}\left(\mathrm{mg} / \mathrm{L} \mathrm{O}_{2}\right)=\frac{(\boldsymbol{A}-\boldsymbol{B})(\boldsymbol{N})(\mathbf{8 0 0 0})}{\boldsymbol{m l \text { contoh } - \boldsymbol { u j i }}}$

Dimana :

$\mathrm{A}=$ volume larutan FAS yang dibutuhkan untuk blanko, $\mathrm{mL}$;

$\mathrm{B}=$ volume larutan FAS yang dibutuhkan untuk contoh, $\mathrm{mL}$;

$\mathrm{N}=$ normalitas larutan FAS.

\section{Hasil dan Pembahasan \\ Pengaruh Waktu Fermentasi Terhadap Persentase Penyisihan Chemical Oxygen Demand (COD)}

Pengaruh waktu fermentasi terhadap persentase penyisihan COD dapat dilihat pada gambar 1. 


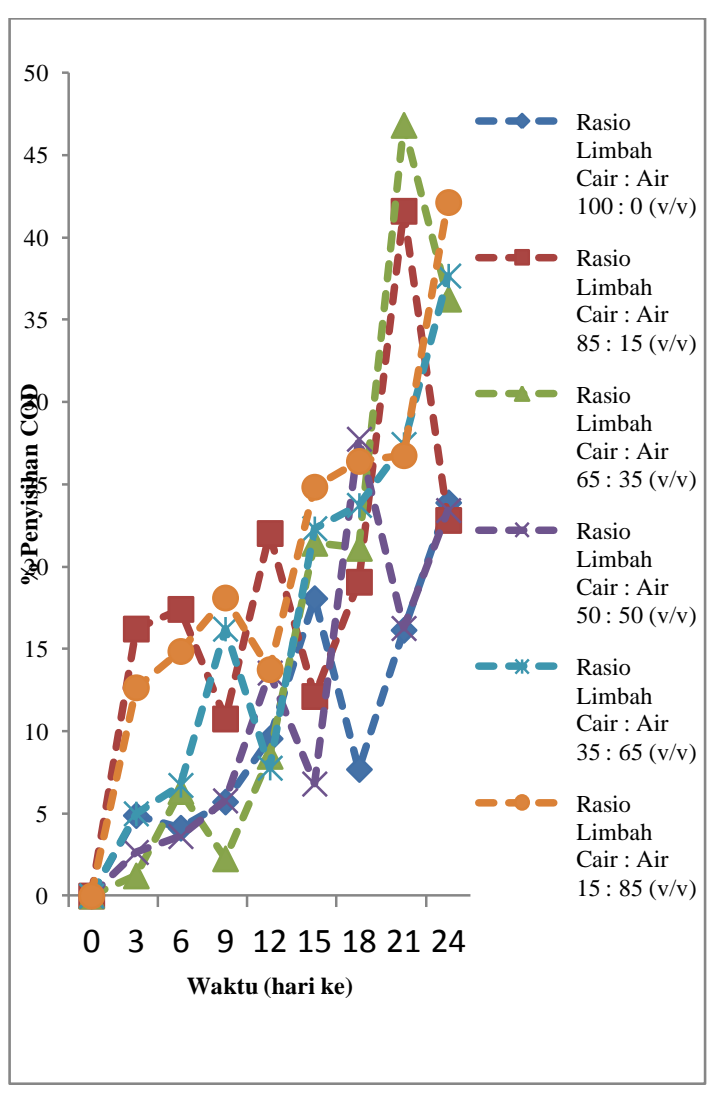

Gambar 1. Pengaruh Waktu Fermentasi Terhadap \% Penyisihan COD (COD-remove) Pada Beberapa Komposisi Sampel

Dari gambar 1 dapat dilihat bahwa waktu fermentasi terhadap \% penyisihan COD (CODremove) diperoleh hasil yang fluktuatif. Pada hari ke-24 waktu fermentasi dengan perbandingan 100:0 didapat \% penyisihan COD (COD-remove) sebesar 23,89\%; pada perbandingan 85:15 didapat \% penyisihan COD (COD-remove) sebesar $22,82 \%$; pada perbandingan 65:35 didapat \% penyisihan COD (COD-remove) sebesar 36,26\%; pada perbandingan 50:50 didapat $\%$ penyisihan COD (COD-remove) sebesar 23,42\%; pada perbandingan 35:65 didapat $\%$ penyisihan COD (COD-remove) sebesar $37,67 \%$ dan pada perbandingan 15:85 didapat $\%$ penyisihan COD (COD-remove) sebesar 42,14\%.

Berdasarkan teori, skala pilot plant di lapangan lebih sulit dikendalikan karena adanya beberapa faktor utama yang harus dijaga seperti suhu, $\mathrm{pH}$, pengadukan (resirkulasi) dan kondisi reaktor [14].

Limbah pengolahan singkong juga mengurangi air sungai oksigen terlarut karena kebutuhan oksigen tinggi. Okafor (2008) juga melaporkan konsentrasi tinggi sianida dalam singkong tanah menerima limbah [11].

Perbedaan pengenceran memberikan pengaruh terhadap konsentrasi perombakan COD.
Perombakan pada rasio pengenceran 1:1 relatif lebih tinggi dibandingkan pengenceran 1:3, karena perombakan yang terjadi akibat aktivitas mikroba. Pertumbuhan dan aktivitas mikroba sangat dipengaruhi tersedianya nutrisi dalam subsrat, $\mathrm{pH}$, dan suhu. Keuntungan lain dari pengolahan secara anaerob adalah dihasilkannya pupuk dari limbah sisa [10].

Ubi kayu mengandung racun glukosida sianogenik (linamarin dan lotaustralin) yang sewaktu hidrolisis dapat menghasilkan asam sianida dan glukosa. Racun ubi kayu dalam kadar yang tinggi dapat berakibat fatal atau mengakibatkan penyakit keracunan yang dinamakan tropical ataxic neuropathy. Kandungan tiosianat di dalam serum darah bila cukup tinggi dapat mengganggu pekerjaan kelenjar gondok sehingga penderitanya dapat terserang penyakit gondok (goitre) atau kekerdilan (cretinism) [16] diambil dari [9].

Sianida dimasukkan dalam standar persyaratan kualitas air minum, oleh karena sebagai single-dose, 50-60 mg adalah bersifat fatal, intake sebesar 3-5 mg/hari tidak menimbulkan gangguan begitu juga untuk single-dose sebesar 10 mg. Konsentrasi sebesar $0,2 \mathrm{mg} \mathrm{L}-1$ akan bersifat netral bagi ikan tawar untuk kontak selama 2 hari. Chlorinasi akan mengubah sianida menjadi cyanogen chloride yang mempunyai oral toxicity yang akut 1/20 dari sianida [8] diambil dari [9].

Pengenceran ini juga dilakukan untuk melihat seberapa besar dampak dari sianida yang terjadi ke lingkungan. Ternyata, setelah dilakukan penelitian tidak mempengaruhi hasil fermentasi.

Limbah cair tapioka yang dipergunakan dalam penelitian ini tidak memenuhi persyaratan baku mutu limbah industri tapioka yang sudah beroperasi dalam SK MENLH KEP51/MENLH/I0/1995 karena kadar COD limbah cair tapioka lebih besar dari pada $300 \mathrm{mg} \mathrm{L}^{-1}$ yaitu sebesar $1746 \mathrm{mg} \mathrm{L}^{-1}$. Selama masa fermentasi selama 24 hari nilai COD dalam limbah berkurang menjadi $315 \mathrm{mg} / \mathrm{L}$, sehingga belum dapat memenuhi persyaratan baku mutu.

\section{Kesimpulan}

Persentase penyisihan COD (COD-remove) terbesar adalah pada perbandingan limbah cair industri tapioka : air sebesar 15:85 didapat 42,14\% dimana nilai COD pada hari ke-0 adalah 1723 $\mathrm{mg} / \mathrm{L}$ setelah hari ke-24 adalah $997 \mathrm{mg} / \mathrm{L}$.

\section{DAFTAR PUSTAKA}

[1] A. O. Ubalua, "Cassava Wastes: Treatment Options and Value addition Alternatives", African Journal of Biotechnology, 6(18) 2007 : hal. 2065-2066 
[2] Abu Hanifah, Cristine Jose dan Nugroho. "Proses Pembuatan Biogas." Skripsi, Fakultas Matematika dan Ilmu Pengetahuan Alam, Universitas Riau, 1999, hal. 9

[3] Alfi Rumidatul. "Efektivitas Arang Akif Sebagai Adsorben Pada Pengolahan Air Limbah." Tesis, Sekolah Pascasarjana Institut Pertanian Bogor, Bogor, 2006, hal. 8.

[4] Anthony Manoni Mshandete dan Wilson Parawira, "Biogas Technology Research in Selected Sub-Saharan African Countries- A Review," African Journal of Biotechnologhy, 8(2) 2009: hal. 2.

[5] Ardhiles Widianta dan Widi Prima Deva (2008). "Ubi Kayu (Manihhot esculenta) Sebagai Bahan Alternatif Pengganti Bensin (Bioethanol) yang Ramah Lingkungan." SMA Negeri 6 Bengkulu, Bengkulu. Diakses pada tanggal 3 Mei 2012 dari wordpress.

[6] Budi Santoso, "Proses Pengolahan Air Buangan Industri Tapioka," Jurnal Ilmiah Teknologi dan Rekayasa, 15(3) 2010 : hal. 215.

[7] Bukan Koran Biasa (2005). "Limbah Tapioka." Diakses pada tanggal 14 Oktober 2013.

[8] C.T. Sutrisno dan E. Suciastuti, Teknologi Penyediaan Air Bersih (Jakarta: Rineka Cipta., 1991).

[9] Dipa Alam Vegantara. "Pengolahan Limbah Cair Tapioka Menggunakan Kotoran Sapi Perah Dengan Sistem Anaerobik." Departemen Ilmu Produksi Dan Teknologi Peternakan, Fakultas Peternakan, Institut Pertanian Bogor, 2009.

[10] Dodik Lutfianto, E. Mahajoeno dan Sunarto. "Pengaruh Macam Limbah Organik dan Pengenceran Terhadap Produksi Biogas dari Bahan Biomassa Limbah Peternak Ayam," Jurnal Bioteknologi, 9(1) 2012 : hal 18-25.

[11] Elijah I. Ohimain, Daniel I. Silas-Olu, dan Joy T. Zipamoh (2013). "Biowastes Generation by Small Scale Cassava Processing Centres in Wilberforce Island, Bayelsa State, Nigeria”. Greener Journal of Environmental Management and Public Safety, 2, 051-059.

[12] Fitri, "Produksi Angkak oleh Monascus purpureus Dalam Medium Limbah Tapioka, Ampas Tapioka dan Ampas Tahu." Buletin Teknik dan Industri Pangan, V(3), 2009.

[13] Garcelon dan Clark (2007). "Komposisi biogas.” Diakses pada tanggal 29 April 2012.

[14] Marhento Wintolo dan Rochman Isdiyanto, "Prospek Pemanfatan Biogas Dari Pengolahan Air Limbah Industri Tapioka," Jurnal Ketenagalistrikan dan Energi terbarukan, 10(2) 2011 : hal. 103-112.
[15] Miss Wantanee Anunputtikul. "Biogas Production From Cassava Tubers." Tesis, Master of Environmental Biology, Suranaree University of Technology, Thailand, 2004, hal. 2 .

[16] P. S Tjokroadikoesoemo, HFS dan Industri Ubi Kayu Lainnya (Jakarta: PT. Gramedia., 1986).

[17] Teguh Wikan Widodo, Akhmad Asari, Ana. N, Elita R, "Rekayasa dan Pengujian Reaktor Biogas Skala Kelompok Tani Ternak," Jurnal Enjiniring Pertanian, IV(1) 2006 : hal. 41-42.

[18] Tri Widayatno dan Sriyani. "Pengolahan Limbah Cair Industri Tapioka Dengan Metode Elektroflokulasi." Prosiding Seminar Nasional Teknoin Bidang Teknik Kimia dan Tekstil, Jurusan Teknik Kimia, Fakultas Teknik, Universitas Muhammadiyah Surakarta, 2008, hal: 1, ISBN 978-979-398015-7. 